\title{
Study and Evaluation of the Factors That Determine the Quality of Marketing Education in Higher Education Institutions in The Kingdom of Saudi Arabia
}

\author{
Somaia Osman Mohamed Abdelgadir ${ }^{1} \&$ Ahmed Osman Ibrahim Ahmed ${ }^{2}$ \\ ${ }^{1}$ Faculty of Economics and Administrative Sciences, Imam Mohamed Bin Saud Islamic University, Saudi Arabia \\ ${ }^{2}$ Business Administration Department, College of Applied Studies and Community Service, Imam Abdul Rahman \\ Bin Faisal University, Saudi Arabia \\ Correspondence: Ahmed Osman Ibrahim Ahmed, Business Administration Department, College of Applied \\ Studies and Community Service, Imam Abdul Rahman Bin Faisal University, Saudi Arabia.
}

Received: December 1, 2020 Accepted: December 31, 2020 Online Published: February 19, 2021

\begin{abstract}
Objective: The tremendous growth in the preparation of higher education institutions for management - marketing, has resulted in the need for and necessity to discuss the quality of that education. From here, the aim of this research was to determine the factors that affect the quality of management education in the Kingdom of Saudi Arabia and to clarify its nature and importance, and the mutual effects on the quality of learning outcomes for marketing education at the individual student and program level, and at the level of the educational institution and its competitiveness.
\end{abstract}

Design / Methodology: The determination of the factors affecting the quality of management education through a review of the literature and then testing its validity and its effects on the quality of marketing education outcomes at the individual, program, and institution level through practical study using survey lists for the teaching courses of government and private universities in the Kingdom of Saudi Arabia.

Findings: The studies showed that almost all of the factors studied are highly reliable among themselves, and that they must be seen as coherent, when analyzing their impact on the learning outcomes of marketing education.

Applications: The study provided guidance for, administrators, curriculum and course designers, and marketing teachers, to design high-quality marketing-management education programs, and in developing a self-diagnostic tool in which universities can determine their susceptibility to success and competition.

Rooting / value: the current literature has shed light on the factors affecting the quality of management education. However, it was taken separately. Therefore, the research contributes to the existing literature by identifying the interrelationships between these factors, which have a role in improving the quality of marketing education.

Keywords: higher education institutions, quality of management education, quality of marketing education, outputs of marketing education, quality improvements, marketing education, Saudi Arabia

\section{Introduction}

Despite what happened in the Kingdom of Saudi Arabia i.e. The huge increase in the numbers of institutions of higher education for management and marketing, which amounted to 41 institutions (22 public universities and 19 private institutions) (Statistics of the Ministry of Higher Education for the academic year, 2015-2016). This is an important indicator of growth and prosperity. However, the most important aspect of preparing these institutions is the quality of the education provided, especially with the increasing importance of management education in achieving economic development and the help of organizations in creating a competitive advantage (Carneiro, 2004), and also the special importance of marketing education, both in the current education institutions as a result of the popularity and preference it has among students and thus a wide spread of university and post graduate study, or because of its importance as a job in business organizations to include many activities ,carried out by managers and employees to create added value for their customers in ways that their competitors cannot be imitated, and also the responsibility of marketing managers to make decisions that have a significant impact on the economies of companies and thus the national economy, enabling us to say that marketing education has become a great importance in strengthening national competitiveness (Gneezy, A., 2017). 
And as the universities are based on the funding restrictions that they face from governments, and are seeking to improve their classification at the world level, they have become more willing to harmonize quality practices and systems, and pay attention to obtaining accreditation for quality, whether from national or international accreditation agents. Based on what the quality of education plays a vital role in the success of educational institutions, which led to a large and continuous increase in preparing colleges of administration to seek accreditation. Based on the achievements of international recognition of providing well-qualified graduates, who are able to compete, while improving the competitive position of those colleges in comparison to others. It also has become a basic criterion for students to choose between those institutions where learning outcomes for students and the availability of employment opportunities are determined based on this. (Sahney et al., 2004).

Despite this, there were many criticisms and questions about the quality of education management, with the emergence of many allegations that marketing education in particular suffers from a widening gap between the academic aspects and practices (Tapp, 2004). And traditional marketing strategies do not work well in the face of turmoil in the current business environment, with problems in appointing graduates of that education, which have become plagued by business organizations looking for graduates with specific specifications, and higher education institutions that seek to provide desirable graduates in the labor market (Baruch, 2009; Datar et al., 2011).

And if some studies have dealt with issues of marketing education such as those that dealt with the concepts of marketing (Homburg et al, 2017), or professional aspects and practical experiences in marketing education (Gneezy, A., 2017), methods of teaching marketing (Kapasi, I. and Grekova, G., 2018). However, it appears that insufficient attention has been paid to the quality of the current teaching of marketing. Also, the few studies that focused on studying the quality of management teaching and that if they came to define a number of factors that affect them, but they have been focused on - and largely - in isolation from each other. While the interactions between them are important as they do not operate independently in the environment, and fall under the classification of inputs, environmental variables or outputs that interact to formulate the complex system of education (Biggs, J. and Tang, C., 2011)). Which calls for the need to study the assumptions on which current practices of teaching management and thus marketing education have been placed? Especially for countries seeking to compete on a global scale. Thus, the current research contributes to the existing literature by proposing a framework for mutual relations between those factors affecting the quality of management and marketing education in order to continuously improve the quality and achieves international recognition of the educational institution by providing well-qualified and competitive graduates and improving its competitive position compared to others. More specifically, the objectives of the study were as follows:

-Determining the factors and variables that affect the quality of management education by reviewing the literature.

-To suggest a framework for the quality of marketing education through an explanation of the nature and importance of relationships between factors and variables affecting the quality of management education, which leads to high levels of quality learning outcomes for marketing at the individual and enterprise level.

This study was written in the Kingdom of Saudi Arabia, but it took into account common factors in higher education institutions for management and marketing around the world. And the means of higher education institutions in the research all kinds of institutions of higher education that provide education for marketing, whether they are independent colleges for administration, or departments in colleges, and both governmental and private. Marketing education also refers to university education and above university courses.

Accordingly, the study contained the following sections: Section 2 dealt with the theoretical background of the study, while Section 3 describes the hypothetical relationships between variables, while Section 4 deals with research design and methodology for the practical study of testing the hypothetical relationships, section 5 presents an analysis of the findings, and section 6 deals with the conclusion of research and applications limits and researches received.

\section{Theoretical Background}

\subsection{Modern Trends in Marketing Education:}

The modern definition of marketing as established by the American Marketing Association (Pride et al, 2015) states that "activities and processes defined by organizations to create, present, deliver, and exchange valuable offers to customers, clients, partners, and society as a whole". From what it can be said that the modern definition refers in more detail to the administrative process where customers, clients and partners constitute the main focus area, which benefits the society as a whole.

Based on this definition, the studies have come to define some of the current general trends in marketing education represented in: the importance of follow-up and familiarity with what is happening in the external environment. A 
major shift in marketing focus from the function of delivering the product to the market to managing the process of discovering consumer needs and desires and trying to satisfy them in strategic ways (Ellis and Waller, 2011). There is increased emphasis on product development, management and associated areas such as service marketing and community marketing. The improvement in supply technology and its applications on the local and global markets also resulted in a reduction in focus on these issues and its replacement with attention to how computers and the Internet are used in this (Sheedy and Russell, 2007). Also, the growth of markets, increased competitiveness, and greater availability of communication technology has shifted the focus in marketing education to emphasizing the importance of marketing communication. The consequence of the increase in both competition and complexities in the market environment resulted in an increased interest in applying the latest marketing information derived from research findings, especially with increased availability of technology and statistical analyzes.

\subsection{Marketing Education in Higher Education Institutions in The Kingdom of Saudi Arabia}

Marketing education in higher education institutions in the Kingdom of Saudi Arabia has many influences, such as: changes in the external environment of the country and around the world. Availability of educational materials: such as textbooks, whether prepared locally or which have been adapted to suit the local environment, academic articles, case studies, academic research papers, the change and development of technologies supporting marketing, a wealth of information available to academics and practitioners from scientific journals, and conferences at the local country level or globally, huge lists of references and publications online. An improvement and growth in methods to increase the efficiency of academics through the availability of crosses outside the country, and the availability of communication technology, using the internet, which facilitated attending conferences and enhanced the quality of information sharing.

\subsection{Quality in Higher Education Management - Marketing}

\subsubsection{Quality in Higher Education}

(Cheng and Tam, 1997) concluded that the concept of quality in higher education is shrouded in mystery and controversy. Based on what is included in the education of a large number of beneficiary groups with diverse and complicated interests, it is possible that each of them has its own definition of quality. From this many studies were conducted on examining institutional inputs, processes, and outputs to determine quality in higher education (Sahney et al, 2010. In general, many of them concluded that the concept of quality in higher education can be defined by defining a set of dimensions of inputs, outputs, and associated operations (Holdford and Patkar, 2003).

There are a number of national and international accreditation entities to apply quality and accreditation standards, whether at the enterprise level as a whole, or academic programs. Examples include what is found in the Kingdom of Saudi Arabia under the name "National Center for Academic Accreditation and Assessment (NCAAA)", which was previously known as the "National Authority for Academic Assessment and Accreditation" as a national accreditation, as an agent that grants accreditation to higher education institutions and programs. Or there are worldwide accreditation agents for different branches of science such as The American Association of Collegiate Schools of Business (AACSB). And if the objectives of accrediting agents differ, based on the branch of science subject to accreditation, the accreditation standards are relatively similar and generally tend to focus on ensuring high quality in inputs and operations (Chalmers, 2008) which in turn leads to the quality of outputs and results.

Several studies have addressed the obstacles to implementing quality, and have indicated that they are similar to those in the industry such as: resistance to change, lack of sufficient resources for quality applications, and employee training (Bhat and Rajashekhar, 2009). Other studies have also identified (Juan and Gavin, 2015) a number of obstacles facing quality applications in higher education were: difficulties in determining the outcomes of higher education and clients and measuring basic learning processes, the absence of standards that reflect customer requirements, weak or lack of clear management responsibility for quality, difficulty in controlling teaching in the returning higher education institutions to what there is variety in educational programs, teaching methods and accompanying processes, places for providing education, difficulties in controlling processes and people, and other obstacles, in addition to the differences in concepts about higher education that may lead to different concepts of educational quality (Chalmers, 2008), which makes It is a shame to reach one set of institutional standards that are valid for implementation in all countries.

\subsubsection{Quality in Management Education -Marketing}

Regardless of the shouts in recent years of accreditation and quality, attention to quality management education is as old as management education itself. As the American Association of Collegiate Schools of Business (AACSB) began in 1926 to set standards for management colleges, it was followed by many associations and similar 
institutions in many countries such as the European Foundation for Management Development (EFMD), which established in 1998 the Quality Improvement System Accreditation Program (EQUIS (Oza and Parab, 2012) and others.

On the nature of quality in management education - marketing, Punia and Kundu (2005) indicated that it is "not a unified concept but it rather depends on a combination of a number of dimensions and factors." Manimala (2006) also concluded that the quality of that education is a multidimensional structure and its maintenance and improvement require simultaneous performance in several directions. Likewise, Oza and Parab (2012), in his study of quality in management education - marketing, came up with a three-pillar model consisting of different elements at the level of the education system, the institutional level, and the level of faculty members.

And on the reasons for the obstacles that faced quality applications in management education - marketing. Studies have attributed it to: the actual number of marketing teachers participating in what may be called an "education quality agenda", which makes it difficult to know what teachers may consider quality in higher education (Hayden, HE and Chiu, MM, 2015)). Also, most of the information on management education has originated in the United States of America, which may be largely unfit for application in other countries (Homburg et al, 2017), and what may lead to continuous changes in the expectations of individuals from the rapid obsolescence of administration education entries that have been approved Previously Gneezy, A., 2017).

\subsection{Higher Education Inputs and Outcomes for Management - Marketing}

\subsubsection{Inputs of The Higher Education System of Administration - Marketing}

Higher education is a complex system that contains many inputs and outputs, and where various activities and operations are carried out. This system can be described as an input model - transformative process - output, which is a widely accepted and recognized model in operations management writings for process improvement (Slack et al., 2016). Inputs refer to the resources used to convert something, or that are being transferred. In higher education, inputs can be categorized as human resources (faculty, students, and administrators), material resources, and financial resources. Outputs can be classified into three important components: graduates, research results, and community service. The conversion process refers to activities that convert inputs into outputs during value-added performance. These activities are administration, teaching, learning, research and service.

\subsubsection{Higher Education System Products for Management - Marketing}

In recent decades, widespread interest in learning outcomes has emerged, and how they are delivering diverse societal needs. Accordingly, international trends in higher education were characterized by a focus on student learning outcomes as an emerging measure of institutional excellence, with ideas shifting from the traditional view of what constitutes high-quality education from a focus on what teachers provide to a particular interest in what learners can absorb and accomplish in an effective and realistic manner (Ewell, 2008).

\subsection{Factors Affecting the Quality of Higher Education Management}

Based on what the researcher did from a review of previous studies, factors affecting the quality of higher education for the administration were reached, which got agreement between most of the researches that addressed the topic: financial resources, material resources, faculty members, leadership, decisions and curricula, teaching and learning methods the interaction between the establishment and the industry, extracurricular activities. Below is a detailed study of these factors:

\subsubsection{Financial Resources}

Funding scarcity is the biggest challenge facing higher education institutions of management - marketing (Rao and Hans, 2011). These funds may come from student fees, government grants, industry contributions, and more. In order to finance the needs of the material resources required for management education - Thomas and Thomas, 2011). Such as expenses for teaching and learning, research, library, information technology, student services, and social activities.

\subsubsection{Material Resources}

According to what (Blin, 2015) indicated, future business schools will be those with the material resources that "facilitate the diffusion of knowledge in time and space to create global societies to share and exchange knowledge." Given the recent trends in management education and marketing mentioned above, it can be said that the material resources required for the effectiveness of that education are: classrooms appropriate for the effectiveness of interactions and discussions between students and their teachers, computer labs labs, libraries, electronic databases, and the like Blin, 2015; Shra, 2013; Rao and Hans, 2011). 


\subsubsection{Faculty Members}

The umbrella under which the faculty members fall is different from one accreditation to another. In the Kingdom of Saudi Arabia, the National Center for Academic Accreditation ranked NCAAA (formerly the National Academic Accreditation Authority) faculty members in the employment standard - with the change of the name "faculty members" to "faculty" (Quality Assurance and Accreditation Standards, 2009). It was common for all management accreditation systems and programs to focus on requirements for qualified faculty. With its identification in dimensions, it is a reflection of the interaction between the four main activities of management (Engwall and Zamagni, 1998), namely: practice, research, education, and consulting. For example, Carneiro (2004) stressed that management academics must have workplace practices. On the basis that the practical experience in management practices is considered a desirable addition within the qualifications of the academic academy because it contains the views of the real world, and therefore a different kind of credibility strengthens and enhances the objectives of the economic development of management education

\subsubsection{Leadership}

Most studies that dealt with quality in higher education indicated leadership as an important factor in factors affecting the quality of management education Bush (2007) and Thomas and Thomas (2011). And leadership indicates that "the leader has the ability to influence groups of individuals in the organization to achieve common goals" (Thomas and Thomas, 2011) Ritika et al (2014) also emphasized that the quality of leadership entails significant differences in learning outcomes at the enterprise level, and that leadership is the main criterion for ensuring availability of all other factors associated with quality. As it leads to the availability of adequate financial resources, which in turn leads to the availability of infrastructure and material resources, which leads to excellence in academic aspects, extracurricular activities and other factors such as the interaction between the educational institution and business organizations, and other important factors for the quality of management education.

\subsubsection{Courses and Curricula}

The multiple dimensions of management are reflected in planning, improving and increasing the quality of curricula and courses. For example, Carneiro (2004) distinguished between the science of management and other branches of science, and pointed out that the science of management represents "a gathering of many sciences to understand and absorb them, and the performances or actions" and, accordingly, he stressed the necessity of providing curricula and methodologies with a balance between the different branches of academic science that contribute to this field. Jain et al (2013) tackled the topic of internationalizing management education as an incentive for curriculum designers to integrate a globalization perspective into all aspects of their curricula. In line with the same trend, the emphasis was on the need for all management education programs to include some kind of international topic (Horta et al., 2010).

\subsubsection{Teaching and Learning Methods}

The focus in higher education on student learning outcomes represents a paradigm shift in education philosophy and practices. When using the output-based approach, it is important and necessary to accurately and in details determine what the student needs to do in order to be able to collect those outcomes at the different levels (Biggs and Tang, 2007). Meaning that the activities required by students are linked to each level of learning outcomes for use when planning and choosing teaching and learning activities appropriate to the expected outcomes.

With regard to marketing teaching and learning strategies, the writings have reached: The importance of communication outside the classroom to improve learning (Nkhoma et al, 2018), as it improves social cohesion between students and their teachers, with the availability of asking questions about the subjects of the course, and improving their independence of study skills. Kapasi and Grekova (2018) also indicated the importance of involving students in the learning process through continuous feedback from students represented in (short surveys on issues that students find more or less related to marketing decisions), encouraging discussions and increasing their quality and measured in depth of answers, that students provide during those discussions. And also the importance of complementarity between the theoretical and practical side and the development of student opinions on how the theory works (or does not work) in the specific field, and this is achieved by using case studies that not only increase student learning, but have developed a trend towards the actual reality of marketing uses in working life. With reviewing the researches of scientific journals and discussing those in the classrooms to allow students to estimate how that research can be integrated with the teaching methods used. With marketing linked to other scientific topics (Jones et al., 2017), they can therefore estimate how marketing is a loose science that applies to all organizations around the world. 


\subsubsection{Ongoing Interaction and Links with Business Organizations}

The findings of the studies (Doria et al., 2003) have resulted that higher education institutions of management are no longer able to fulfill the needs of business organizations. Until the links with business organizations have acquired great importance for the quality of management education - marketing. As these links are continuous inputs from organizations to design curricula, train students, and also learn about realistic practices. It includes hands-on training, factory visits, and lectures from external guests, joint projects, workshops and seminars. This in turn affects other factors such as recruitment, research and financial resources.

\subsubsection{Extracurricular Activities}

Based on the fact that recruitment at the present time has become largely dependent on more than just the availability of students and graduates traditional competencies such as critical thinking, quantitative analyzes ethical aspects, and communication. Extracurricular activities have gained equal importance in classroom education (Garland et al., 2011), as most quality management education studies agree on their importance (Rao and Hans, 2011; Garland et al., 2011; Jain et al., 2013), based on what you provide the student with the important and necessary aspects of comprehensive rehabilitation and character development. Examples of extracurricular activities include sports, social and cultural events, and consulting services.

To study the practical factors that affect the quality of management education and its relationship to the quality of marketing education, the researcher compiled those related to material resources and financial resources under the classification of inputs. The factors for designing courses and curricula, teaching and learning methods, and the interaction between the institution and the industry were also grouped under the name of the methods used to present the scientific material. Thus, the factors affecting the quality of management education in the current research were categorized as follows: inputs from financial and material resources, faculty members, leadership, methods used to present the scientific material (and it includes factors related to designing courses and curricula, teaching and learning methods, and interaction between the institution and business organizations), then extracurricular activities.

\section{Assumed Relationships Between Study Variables}

Based on the previous definition of what was mentioned in previous stu dies on the most important factors affecting the quality of higher or outputs, and to achieve the goal of research in improving methods for assessing the quality of marketing education. The variables of the education for management, and based on the consideration of higher education as a system of inputs, transformational processes, outputs study and the assumed relationships between them were as follows:

\subsection{Affiliated Variables}

For practical study, the focus was on identifying dependent variables on the three levels of learning outcomes for marketing education. This means that at the individual student level, at the program level, and at the institutional level. With the incorporation of those related to the level of the individual and the program together as the first dependent variable, which will be called "learning outcomes at the level of the individual and the program", while the second dependent variable represents learning outcomes at the institutional level, which will be called "competitive outcomes", which will be evaluated based on the status of the university or its reputation It is also recognized by students, donors, market competitors, and employment destinations

\subsection{Independent Variables}

As for the independent variables, they were represented by the factors that studies have proven important to the quality of the aforementioned management education, which were categorized in: inputs from financial and material resources, faculty qualifications, leadership, and methods used to provide scientific material, and extracurricular activities. Thus the hypotheses of the research were formulated as follows:

The first hypothesis: The higher level of availability of financial and material resources appropriate for management education is accompanied by: (a) a higher level of learning outcomes for teaching education at the individual student and program level. (b) A higher level of learning outcomes at the educational institution level competitive outcomes.

The second hypothesis: The higher level of management faculty qualifications is accompanied by: (a) a higher level of learning outcomes for marketing education at the individual student and program level. (b) A higher level of learning outcomes at the educational institution level competitive outcomes.

The third hypothesis: The higher level of leadership effectiveness is accompanied by: (a) a higher level of learning outcomes for marketing education at the individual student and program level. (b) A higher level of learning 
outcomes at the educational institution level (competitive outcomes)

The third hypothesis: The higher level of appropriateness of the methods used to prepare and present the scientific material for management education (curriculum design and courses, teaching and learning methods, interaction between the institution and the industry) is accompanied by both: (a) a higher level of learning outcomes for marketing education at the individual student and program level. (b) A higher level of learning outcomes at the educational institution level competitive outcomes.

Fourth hypothesis: The higher level of extracurricular activities accompanies both: (a) a higher level of learning outcomes for marketing education at the individual student and program level (b) a higher level of learning outcomes at the level of the educational institution

\section{Methodology}

\subsection{Research Society}

The research community consists of a comprehensive inventory of the teaching staff in marketing decisions in higher education institutions of administration in the Kingdom of Saudi Arabia, whether they are independent colleges of administration, or scientific departments and programs in colleges. And whether they belong to private or government universities

\subsection{The Sample and Data Collection}

To test the research hypotheses to assess the quality of marketing education, a practical study was conducted among those who teach marketing in the Kingdom's public and private universities. Using a survey list. And distribute them to the vocabulary of the sample. Because there is no comprehensive guide for all those teaching marketing courses in higher education institutions in Saudi Arabia, referring to the websites of the universities under study and making a list. The final list of sample items consisted of individuals who were classified as teachers of marketing decisions in their universities and who can be contacted via e-mail.

The survey was sent to them. With not requesting to register the name, even if they were asked to specify the nature of the university in which they work, whether governmental or private.

The overall response rate was 17\% (excluding 6 lists due to loss and invalidity of data). The respondent's rankings in the final sample were as follows: 215 teachers in government universities, $73 \%$ of the total sample, and 78 from private universities, $26 \%$. The number of women was $202,69 \%$, and men $91,31 \%$. And on the question of whether they got any education outside the home country, the answer rate was $48 \%$ did not get, $22 \%$ got some courses or training programs, $20 \%$ got a master's degree, and $10 \%$ got a doctorate. With regard to years of experience, the following was: $1-4$ years $=34 \%, 5-10$ years $=40 \%$, more than 10 years $=26 \%$. As for the academic degree, the classifications, numbers, and proportions within each classification were as follows: Lecturer and the like $=21 \%$, Assistant Professor $=40 \%$, Associate Professor $=30 \%$, Professor $=9 \%$

\subsection{Measurements}

\subsubsection{Financial and Material Inputs}

The financial resources included expenditures on teaching and learning, research, library, information technology support, student services, social, sports and cultural activities, and the like. The material resources also included the availability of appropriate classrooms, computer labs, libraries and available textbooks and electronic databases. Respondents were asked to score on a scale from 1 to 5 (where $1=$ strongly disagree, $5=$ strongly agree). Cranach's alpha for this variable was 0.7214 , indicating a high degree of reliability for this measure, and the factorial analysis combined all items under one factor latent root $=2.94354$.

\subsubsection{Qualifications of the Teaching Staff}

Items for measuring the qualifications of the teaching staff have been extracted from the characteristics that must be available in the administration teaching staff to adhere to both the quality dimensions derived from the accreditation criteria of the National Center for Assessment and Academic Accreditation, the international standards for management education, and the factors that affect. The quality of management education is as follows: academic experience, degree, international experience, professional experience. And research productivity. For academic experience, answers were scored on a scale of 1 to $3(1=1$ to 5 years' experience, $2=6$ to 10 years' experience, $3=$ more than 10 years' experience $)$. With regard to the degree: $(1=$ Bachelor's degree, $2=$ Master's degree, 3 = Doctorate degree). To assess international experience, respondents were asked to determine whether they had received education or training outside their home country: $(1=$ none or some courses, $2=$ master's degrees, $3=$ doctoral degrees). As for the professional experience, the answers were scored on a scale from 1 to 5 (where 1 $=$ none, $5=$ very much). As for research productivity, it was also 
As for the research productivity, the answers were also recorded on a scale from 1 to $5(1=$ none, $5=$ there is a large degree) and the value of chi-square for this variable was 71.2836, and the Kendall's W scale was 0.3390 (p $<0.0000) \ldots$ These results indicated that there is significant agreement between the respondents' assessments. Factors analyzed all factors in one factor (latent root $=1.87515$ ). As for the research productivity, the answers were also recorded on a scale from 1 to $5(1=$ none, $5=$ there is a large degree $)$ and the value of chi-square for this variable was 71.2836 , and the Kendall's W scale was $0.3390(\mathrm{p}<0.0000) \ldots$ These results indicated that .There is significant agreement between the respondents' assessments. Factors analyzed all factors in one factor (latent root $=1.87515$ ).

\subsubsection{Leadership}

The variable of leadership effectiveness was evaluated by 3 items that focused on effectiveness in: managing the performance of education processes which leads to improvement in those processes, quality improvements in teaching and research leading to empowering and motivating faculty members, managing the performance of body members Teaching leading to support and encouragement of the members. Respondents scored their responses on a scale from 1 to $5(1=\mathrm{I}$ do not agree very much, $5=\mathrm{I}$ agree to a large degree). The chi-square for this variable was $17.0224(p<0.0007)$ and Kendall's W measure 0.264 . These results indicate a low (albeit significant) level of approval among respondent reviews.

\subsubsection{The Methods Used to Provide the Scientific Material}

This variable included: designing curricula and courses, teaching and learning methods, the interaction between the educational institution and industry. The curriculum design and learning was measured using 3 items: the balance between the different branches of science, the integration of the globalization perspective into all topics of the course, the different uses of technology in all aspects of marketing. Respondents scored their responses on the Likart scale from 1 to $5(1=$ none, $5=$ significantly $)$. While methods of teaching and learning were measured using 4 items: feedback from students, integration between theory and practice, methods of using computers, developing and increasing communication between students and their teachers and some of them. Respondents scored their responses on the Likart scale from 1 to $5(1=$ none, $5=$ significantly). The interaction between the educational institution and business organizations was also measured with items: continuous inputs from business organizations to design decisions, visits to business organizations, external lecturers from business organizations, workshops and seminars, joint projects, and practical training. Respondents scored their responses on the Likart scale from 1 to 5 ( 1 = none, $5=$ significantly). Cronbach's alpha for this variable was 0.7356 , indicating an acceptable degree of credibility for this measure. The global analysis classified all items in one factor (latent root $=3.87923$

\subsubsection{Extracurricular Activities}

They were measured using 3 items sporting events, social events, and cultural events. Respondents scored their responses on the Likart scale from 1 to 5 ( $1=$ none, $5=$ significantly). Cronbach's alpha for this variable was 0.7735 , indicating an acceptable degree of credibility for this measure. The global analysis classified all items in one factor (latent root $=2.88211$ ).

\subsubsection{Learning}

\section{Outcomes}

The first dependent variable, which is the learning outcomes of marketing at the individual and program level, was evaluated by 6 items. Respondents were asked to determine whether the learning outcomes of their courses lead to:

1-Knowledge of basic knowledge and theories of marketing science, with the ability to apply them in practical life.

2-The ability to provide innovative solutions to national problems, with critical analysis of current marketing practices

3-Communicating effectively and using technology and the Internet in dealing with changes in the local and global environment

4-Commitment in marketing practices with Islamic values, ethical behavior and respect for others

5-Aligning with the needs of companies, employability, and advancing the career ladder

6-The opportunity to make future studies

Respondents scored their responses on a scale from 1 to 5 (where $1=$ strongly disagree, $5=$ strongly agree). 
Cronbach's alpha for this variable was 0.7994 , indicating a high degree of reliability for this measure. Also, the global analysis classified all items in one factor (latent root $=3.54945$ )

\subsubsection{Competitive Outcomes}

As for the competitive outcomes, which represent the learning outcomes at the institutional level, learning at the enterprise level, or what will be called in the current study, the competitive outcomes have been identified in the following:

-Quality and accreditation certificates obtained by the institution

-The reputation and status of the institution as perceived by students

-The reputation and status of the institution as perceived by donors, and sponsors of various activities in it.

-The reputation and status of the institution as perceived by other comparable institutions

-The reputation and status of the institution as perceived by the employers.

Respondents recorded their responses on a five-point scale where $(1=$ bad position, $5=$ good position). Cronbach's alpha for this variable was 0.8386 . Pointing a high degree of credibility to this scale. The global analysis also classified all items in one factor (latent root $=2.49961$ ).

Respondents scored their responses on a scale from 1 to 5 (where $1=$ strongly disagree, $5=$ strongly agree). Cronbach's alpha for this variable was 0.7994 , indicating a high degree of reliability for this measure. Also, the global analysis classified all items in one factor (latent root $=3.54945$.

\section{Findings}

\subsection{Descriptive Statistics}

Table 1 shows descriptive statistics including averages and standard deviation of the variables.

Table 1. Descriptive Metrics for Variables

\begin{tabular}{lll}
\hline variables & Average & standard deviation \\
\hline $\begin{array}{l}\text { Inputs from financial and } \\
\text { material resources }\end{array}$ & 2.08 & $\mathbf{0 . 6 9}$ \\
$\begin{array}{l}\text { Qualifications of the teaching } \\
\text { staff }\end{array}$ & 1.96 & $\mathbf{0 . 7 9}$ \\
Leadership & 2.72 & $\mathbf{1 . 0 9}$ \\
Methods used in presentation of \\
scientific material & 2.18 & $\mathbf{0 . 7 5}$ \\
Extracurricular activities & & \\
Learning Outcomes & 2.79 & $\mathbf{0 . 9 3}$ \\
Competitive Outputs & 3.34 & $\mathbf{0 . 8 5}$ \\
Note: $\mathrm{n}=2932.08$ & 3.25 & $\mathbf{0 . 7 6}$ \\
\hline
\end{tabular}

\subsection{Data Analysis}

The data were analyzed using three methods: 


\section{1-Correlation Matrix}

2-multivariate analysis of variance (MANOVA)

3-Two-stage least squares regression analysis

MANOVA analysis was chosen because it is an appropriate method for testing theory in the early stages of presentation, where research questions are more concerned with the existence of relationships than with interest in its strength (Schmelkin, 1991). If the findings are important, then it is appropriate to perform an individual analysis. Multiple regressions analyze for each dependent variable (which is what happened in this study) the matrix of correlation between independent and dependent variables were set out in Table 2 (Learning Outcomes) and Table 3 (Competitive Outputs). These results indicated partial acceptance of the assumptions.

The MANOVA test was used to assess the overall effects of independent variables on dependent variables (learning outcomes and competitive outcomes). The value of multivariate F was important (Wilks'lambda 0.26; $p=0.000$ ), which showed that dependent variables were related to the variance in the independent variables.

\subsection{Hypothesis Examination}

The two-stage least squares regression analysis (SPSS) was used to evaluate the effect of each model variable on the two dependent variables (learning outcomes for marketing education, and competitive outputs for marketing education

\subsubsection{Assumed Relationships with Learning Outcomes}

Table 4 shows the results of regression analysis with the outputs of marketing education learning as a dependent change. The results indicated that some of the assumed relationships of the model are statistically significant at ( $p$ $<0.01$ ). Also, independent variables explained about $34 \%$ of the diversity in the outputs of marketing education learning

Table 4 also shows the results of the hypothesis test $1-a$, which states that the higher level of availability of financial and material resources is associated with a higher level of learning outcomes. The positive relationship between inputs from financial resources, material resources, and learning outcomes was confirmed when the governing variable (university type) included the second model. Which shows that the supposed relationships are conditional on the type of institution (governmental or private)? As for hypothesis 2 - a, there has been evidence of the relationship between the qualifications of the teaching staff and their impact on learning outcomes. Especially when including the governing variable (type of university). Thus, it appears that the positive relationship is conditional on the existence of differences between Saudi public and private universities in the terms of qualifications standards and faculty evaluation

The findings also confirmed the positive relationship between the effectiveness of leadership and the level of learning outcomes as stated in the hypothesis 3- a. While the exploratory results shown in Table 3 suggested that the effectiveness of leadership does not have a positive relationship with learning outcomes) but when adding the ruling variable (type of university) as in (Model 2) it was an enhancement of the positive relationship. It is suggested that the impact of leadership on learning outcomes is affected by the different working environments of public and private universities. This may be due to the fact that private universities often have more freedom to make decisions than in public universities, which have a work environment characterized by bureaucratic rules and control.

Table 2. Matrix correlation between learning outcomes and variables

\begin{tabular}{|c|c|c|c|c|c|c|c|}
\hline \multirow[t]{2}{*}{ Hypothesis } & \multirow[t]{2}{*}{ Average } & \multicolumn{6}{|c|}{ Medium learning outcomes } \\
\hline & & $\begin{array}{l}\text { Making } \\
\text { future } \\
\text { studies }\end{array}$ & $\begin{array}{l}\text { Compli } \\
\text { ance } \\
\text { with } \\
\text { compan } \\
\text { ies }\end{array}$ & $\begin{array}{l}\text { complia } \\
\text { nce with } \\
\text { ethics }\end{array}$ & $\begin{array}{l}\text { Commu } \\
\text { nicating } \\
\text { with } \\
\text { effective } \\
\text { ness }\end{array}$ & $\begin{array}{l}\text { Providi } \\
\text { ng } \\
\text { innovat } \\
\text { ive } \\
\text { solutio } \\
\text { ns }\end{array}$ & $\begin{array}{l}\text { Knowled } \\
\text { ge- } \\
\text { building }\end{array}$ \\
\hline $\begin{array}{l}\text { inputs } \\
\text { financial }\end{array}$ & $0.2135^{*}$ & $0.1153^{*}$ & $\begin{array}{l}0.2613 \\
*\end{array}$ & $0,2125^{*}$ & $\begin{array}{l}0.2916^{*} \\
*\end{array}$ & $\begin{array}{l}0.2171 \\
*\end{array}$ & $0.2265 *$ \\
\hline material resources & $0.2885^{*}$ & $0.2736^{*}$ & & $0.2249 *$ & & & $0.2488^{*}$ \\
\hline $\begin{array}{l}\text { Qualifications of the } \\
\text { teaching staff }\end{array}$ & $\begin{array}{l}0.3507 * * \\
0.3685\end{array}$ & $\begin{array}{l}0.2426^{* *} \\
*\end{array}$ & $\begin{array}{l}0.2489 \\
*\end{array}$ & $\begin{array}{l}0.3475^{*} \\
* *\end{array}$ & $\begin{array}{l}0.1559^{*} \\
0.2124^{*}\end{array}$ & $\begin{array}{l}0.2547 \\
0.2475\end{array}$ & $\begin{array}{l}0.3293 * * \\
*\end{array}$ \\
\hline
\end{tabular}




\begin{tabular}{|c|c|c|c|c|c|c|c|}
\hline & & 0.4714 & 0.2675 & $0.3368^{*}$ & * & ** & $0.1635 *$ \\
\hline . Leadership & 0.3723 & & $* *$ & & 0.2333 & 0.2459 & \\
\hline The methods used in & & $0.2579 *$ & 0.3856 & $0.3113 *$ & & & $0.2978 *$ \\
\hline presenting the & & & & $*$ & $0.3416^{*}$ & 0.1726 & \\
\hline scientific material. & & & 0.3588 & & & & \\
\hline $\begin{array}{l}\text { Extracurricular } \\
\text { activities }\end{array}$ & & & * & & & & \\
\hline
\end{tabular}

As for Assumption 4-A, which states that there is a relationship between the methods used to present the scientific material and learning outcomes, the results in Table 3 have confirmed that relationship. Although the relationship was strong and important, it was also sensitive to the differences between the user from those methods in public and private universities

Table 3. Matrix correlation between competitiveness outcomes and variables

\begin{tabular}{|c|c|c|c|c|c|c|}
\hline \multicolumn{7}{|c|}{ Competitive Outputs } \\
\hline Hypothesis & $\begin{array}{l}\text { Averag } \\
\mathrm{e}\end{array}$ & $\begin{array}{c}\text { Medium } \\
\text { employe } \\
\text { rs }\end{array}$ & $\begin{array}{l}\text { Competitors 'percepti } \\
\text { ons }\end{array}$ & $\begin{array}{c}\text { Donors' } \\
\text { perceptio } \\
\text { ns }\end{array}$ & $\begin{array}{c}\text { Students 'perceptio } \\
\text { ns }\end{array}$ & $\begin{array}{c}\text { Quality } \\
\text { certificat } \\
\text { es }\end{array}$ \\
\hline $\begin{array}{l}\text { Financial and } \\
\text { material }\end{array}$ & $\begin{array}{l}0.2508 \\
*\end{array}$ & $0.1725^{*}$ & $0.2393 * *$ & $0.1804 *$ & 0.1425 & $0.2025^{*}$ \\
\hline resources. & & 0.2396 & 0.0685 & 0.2155 & 0.1749 & 0.2323 \\
\hline Qualifications & 0.1523 & 0.1109 & $0.3788 * *$ & 0.0618 & 0.111 & $0.1903 *$ \\
\hline $\begin{array}{l}\text { of the teaching } \\
\text { staff }\end{array}$ & $\begin{array}{l}* \\
0.2658\end{array}$ & $0.1596^{*}$ & $0.1599 *$ & 0.0493 & 0.0645 & $0.1727^{*}$ \\
\hline Leadership & $*$ & $0.1906^{*}$ & $0.1908^{*}$ & 0.1205 & $0.2696^{* *}$ & $0.2869 * *$ \\
\hline $\begin{array}{l}\text { The methods } \\
\text { used in } \\
\text { presenting the } \\
\text { scientific } \\
\text { material. }\end{array}$ & $\begin{array}{l}0.1433 \\
* \\
0.2862 \\
*\end{array}$ & & & & & \\
\hline $\begin{array}{l}\text {--Extracurricul } \\
\text { ar activities }\end{array}$ & & & & & & \\
\hline
\end{tabular}

As for hypothesis 4-a, which deals with the impact of extracurricular activities on the learning outcomes of marketing education, the results in Table 3 showed a positive relationship between extracurricular activities and educational outcomes. However this effect can only be seen when the governing variable (type of university) is included. This is due to the nature of private universities that provide more financial resources, and less student preparation compared to government universities, which allows them to carry out various extracurricular activities such as organizing sporting, social and cultural events to supply their students with more than just traditional competencies, and until their graduates have the comprehensive rehabilitation and personal growth required of Employment agencies. 
Table 4. Analysis of two-stage least squares regression With learning outcomes output as a dependent variable

\begin{tabular}{lll}
\hline \multicolumn{1}{c}{ Variables } & \multicolumn{1}{c}{ Model 2 } & \multicolumn{1}{c}{ Model 1 } \\
\hline -Inputs from financial and material & $2.518^{*}$ & 1.455 \\
resources. & 1.335 & $2.914^{*}$ \\
-QUALIFICATIONS Of the staff. & $3.373^{* *}$ & $2.769^{*}$ \\
-Leadership. & $3.749^{* *}$ & $3.211^{* *}$ \\
-Ways OF providing scientific material. & $2.765^{* *}$ & 1.892 \\
: Extracurricular activities & & \\
Summary statistics & 0.59775 & 0.55472 \\
Multiple R & 0.35728 & 0.30768 \\
R2 & 0.32694 & 0.27782 \\
Adjusted R2 & 0.04913 & \\
4R2 & 11.76678 & 10.29637 \\
F-statistic & 0.0000 & 0.0000 \\
\hline
\end{tabular}

Note $=293 \mathrm{p}<0.10 ;{ }^{*} \mathrm{p}<0.05 ; * * \mathrm{p}<0.01 ; * * * \mathrm{p}<0.000$

In summary, the results showed that higher levels of adherence to quality standards in management education related to inputs from financial and material resources, faculty qualifications, leadership, methods for preparing and submitting scientific material, and extracurricular activities have a positive relationship to learning outcomes in marketing education in Saudi universities

\subsubsection{Assumed Relationships with Competitiveness Outcomes}

Table 5 shows the results of the regression analysis with the competitive outputs of marketing education as a dependent variable. Results showed several hypothetical relationships in the model that were statistically significant (at $\mathrm{p}<0.01$ ). These independent variables showed approximately $40 \%$ of the diversity in the competitive outputs of marketing education.

The results confirmed the validity of hypothesis $1-b$, which states that there is a positive relationship between the availability of financial and material resources and the level of competitive outcomes for marketing education. The relationship was also strengthened by including the ruling variable (type of university) (Model 2).

The results also showed that the faculty qualifications have a positive relationship with the competitive outcomes of marketing education as prescribed in hypothesis 2-b. In fact, members' qualifications emerged as the most influential independent variable in relation to the competitive outcomes of marketing education.

The results also confirmed hypothesis 3-b, which states that there is a positive relationship between leadership and competitiveness outcomes. The results also supported hypothesis 4-b, which provides for a positive relationship between the methods used to present scientific material and the products of competitiveness. This relationship was also strengthened when the ruling variable (type of university) was included in Form 2

Table 5. Analysis Two-stage least squares regression with competitiveness outcomes as a dependent variable

\begin{tabular}{lll}
\hline Vriables & Model 2 & Model 1 \\
\hline - Inputs from financial and material resources. & $2.822^{* *}$ & $2.018^{*}$ \\
-Staff qualifications. & $3.945^{* *}$ & $2.179^{*}$ \\
-Leadership. & $3.715^{* *}$ & $3.605^{* *}$ \\
-Ways used in presentation of scientific materials. & $2.509^{* * *}$ & $2.332^{*}$ \\
-Non-curricular activities & ---- & 1.383 \\
Summarized Statistics & & \\
Multiple R & 0.66828 & 0.5825 \\
R2 & 0.44658 & 0.3958 \\
Adjusted R2 & 0.4195 & 0.3661 \\
4R2 & 0.0539 & \\
F-statistic & 16.54305 & 12.64452 \\
p & 0.0000 & 0.0000 \\
\hline
\end{tabular}


As for imposing 5-b, which states that there is a positive relationship between extracurricular activities and the competitive outcomes of marketing education has not been confirmed. Where the relationship that initially appeared weak (model 1) was excluded when including the governing variable (university type). It can be said that these activities do not affect the products of competitiveness. If it appeared to have an impact on learning outcomes

It can be said that the results in general provided support that the proposed variables are credible in predicting levels of educational quality (as measured by the outputs of marketing education and competitive outputs of marketing education) in marketing programs in Saudi universities

\section{Conclusion, Applications, and Limitations}

The aim of the research was to propose and test a framework of variables to assess the quality of marketing education, which was defined in the items of student learning outcomes, and the university's competitive position. With a study of how the effect of the assumed variables is mitigated when a ruling variable is included

The research has many theoretical and practical applications. With regard to theoretical applications, the study supported the statement that the model of "inputs, process, and outcomes" is useful in studying the quality of the education system, where the inputs are converted into outcomes. Also, the important opinions it presented to the accreditation agents regarding the quality of education specifically, which has special characteristics that distinguish it from the other branches of management science

As for practical applications, they include those of higher education institutions and practitioners in business organizations. For higher education institutions, there are applications at the academic and administrative levels. At the academic level, the focus of the study on the factors affecting the learning outcomes at the individual, program and educational level and the relationships that have been reached can be beneficial for those responsible for marketing programs and decisions in developing educational policies and frameworks for marketing education in order to obtain the best outcomes for student learning and the competitive situation. On the administrative level, the research presented some practical measures that may become a self-diagnostic tool for managers. It also describes the administrative performance that higher education institutions can use to implement competitive strategies for their organizations

For those practicing in companies, the results of the research represent a guide for them to help them in comparing the education obtained by applicants for joining work according to the variables used in their education. It also guides those responsible for training in companies in defining training methods, and in setting goals for developing a career path and the best way to achieve them as well. Last but not least, it provides metrics for managers to evaluate their employees

The limitations of the study are those that are common to all research in education, which is the lack of data, the incompleteness of structuring the educational variables used and automatic self-bias in the sample. However, despite these limitations, the procedures for selecting the sample and validity tests conducted on the variables have somewhat alleviated these difficulties

To enhance the validity of the study and generalize the findings, future research may focus on using more direct measures of the theoretical composition and clarifying the cross-relationships between the variables. Other research may also be based on studying the proposed model in different countries and for various branches of science.

\section{References}

\section{Arabic References}

Statistics of public and private universities (2015-2016). Ministry of Higher Education in the Kingdom of Saudi Arabia.

Alamin Al-Youssef (2015). Total Quality Management in Higher Education Institutions and their impact on evaluation and accreditation. Journal of educational science, 16.

Zayed bin Jamaan bin Attia (2007). Outcomes of higher education institutions in the Kingdom of Saudi Arabia.

UNESCO Forum for Higher Education, Research and Knowledge. Riyadh.

Saeed bin Ali Al-Adadi (2012). Obstacles to the application of TQM in higher education institutions - a field study. The Arab Journal for Quality Assurance of Higher Education, (9).

Fakhria Bint Mohamed Ismail (2007). Higher Education in the Kingdom of Saudi Arabia between Educational Thought and the Culture of Globalization". UNESCO Forum for Higher Education, Research and Knowledge. Riyadh. 
Quality Assurance and Accreditation Standards for Higher Education Institutions (2009). The National Center for Academic Calendar and Accreditation.

\section{Foreign References}

AACSB (2017). Eligibility procedures and accreditation standards for business accreditation. AACSB International - The Association to Advance Collegiate Schools of Business, AACSB, Tampa.

Anto, G. (2011). INDIA 2020: challenges and opportunities in management education. Aweshkar Research Journal, 12(2).

Bernasconi, A. (2003). Private higher education with an academic focus: Chile's new exceptionalism. International Higher Education, 32.

Blin, J. (2015). Quality in higher education: from the diversity of conceptions to the relentless conceptual subjectivity. Creative Education, 6(22).

Bloom, B.S., Engelhart, M.D., Furst, E.J., Hill, W. and Krathwohl, D. (1956), Taxonomy of Educational Objectives, Volume 1: The Cognitive Domain, McKay, New York, NY.

Bush, T. (2007). Educational leadership and management: theory, policy, and practice. South African Journal of Education, 27(3).

Carneiro, A. (2004). Teaching management and management educators: some considerations. Management Decision, 42(3/4). https://doi.org/10.1108/00251740410521800

Datar, S. M., Garvin, D. A., \& Cullen, P. G. (2011). Rethinking the MBA: business education at a crossroads. Journal of Management Development, 30(5). https://doi.org/10.1108/02621711111132966

Ellis, R. B., \& Waller, D. S. (2011). Marketing education in Australia before 1965. Australasian Marketing Journal, 19(2). https://doi.org/10.1016/j.ausmj.2011.03.003

Engwall, L., \& Zamagni, V. (1998). Introduction. In Engwall, L., \& Zamagni, V. (Eds.), Management Education in Historical Perspective, Manchester University Press, Manchester.

Garland, B., Kim, P., Lancaster., P., \& Ponsford, B. (2011). Business and Marketing Student Attitudes Towards Learning Objectives Achieved in Classes and Extra Curricular Activities, Marketing Management Association Educators' Conference Proceedings. Tata McGrawHill, Nashville, TN, 20-22 September.

Hayden, H. E., \& Chiu, M. M. (2015). Reflective teaching via a problem exploration-teaching adaptationsresolution cycle: a mixed-methods study of preservice teachers' reflective notes. Journal of Mixed Methods Research, 9(2). https://doi.org/10.1177/1558689813509027

Holdford, D., \& Patkar, A. (2003). Identification of the service quality dimensions of pharmaceutical education. The American Journal of Pharmaceutical Education, 67(4). https://doi.org/10.5688/aj6704108

Homburg, C., Jozic, D., \& Kuehnl, C. (2017). Customer experience management: toward implementing an evolving marketing concept. Journal of the Academy of Marketing Science, 45(3). https://doi.org/10.1007/s11747-015-0460-7

Horta, H., Veloso, F. M., \& Grediaga, R. (2010). Navel gazing: academic inbreeding and scientific productivity. Management Science, 56(3). https://doi.org/10.1287/mnsc.1090.1109

Jain, R., Sahney, S., \& Sinha, G. (2013). Developing a scale to measure students' perception of service quality in the Indian context. The TQM Journal, 25(3). https://doi.org/10.1108/17542731311307456

Jones, C. M., Green, J. P., \& Higson, H. E. (2017). Do work placements improve final-year academic performance or do high-calibre students choose to do work placements?. Studies in Higher Education, 42(6). https://doi.org/10.1080/03075079.2015.1073249

Juan, J. T., \& Gavin, D. (2016). Trends in quality management research in higher education institutions. Journal of Service Theory and Practice, 26(3). https://doi.org/10.1108/JSTP-10-2014-0230

Lombardi, J., Craig, D., Capaldi, E., Gater, D., \& Mendonça, S. (2001). Quality Engines: The Competitive Context for Research, the Top American Research Universities, The Center Gainesville, Florida.

Oza, V., \& Parab, S. (2012), Three pillars of quality management education in india in the 21 st century. International Journal of e-Education, e-Business, e-Management and e-Learning, 2(1), 67-71. Retrieved from www.ipcsit.com/vol20/44-ICAIT2011-G1018.pdf (accessed 1 July 2012)

Pedhauzer, E., \& Schmelkin, L. (1991), Measurement, Design and Analysis, Lawrence Erlbaum Associates, 
Hillsdale, NJ.

Sahney, S., Banwet, D. K., \& Karunes, S. (2004). Customer requirement constructs the premise for TQM in education: a comparative study of select engineering and management institutions in the Indian context. International Journal of Productivity and Performance Management, 53(6). https://doi.org/10.1108/17410400410556174

shra, V. (2013). Globalization and Indian higher education. Learning Community. An International Journal of Educational and Social Development, 4(1).

Yazid, M. (2018). Input resources indicators in use for accreditation purpose of higher education institutions. Performance Measurement and Metrics, 19(3). https://doi.org/10.1108/PMM-02-2018-0006

Baruch, Y. (2009). To MBA or not to MBA. Career Development International, 14(4). https://doi.org/10.1108/13620430910979862

Bhat, K. S., \& Rajashekhar, J. (2009). An empirical study of barriers to TQM. Implementation in Indian industries. The TQM Magazine, 21. https://doi.org/10.1108/17542730910953031

Biggs, J., \& Tang, C. (2007). Teaching for Quality Learning at University (3rd ed.), Society for Research in Higher Education and Open University Press, Berkshire.

Biggs, J., \& Tang, C. (2011). Teaching for Quality Learning at University (4th ed.), Society for Research in Higher Education and Open University Press, Berkshire.

Chalmers, D. (2008). Indicators of university teaching and learning quality. Report, Australian Learning and Teaching Council, Sydney.

Cheng, Y. C., \& Tam, W. M. (1997). Multimodels of quality in education. Quality Assurance in Education, 5(1). https://doi.org/10.1108/09684889710156558

Doria, J., Rozanski, H., \& Cohen, E. (2003). What business needs from business schools. Business Strategy, 32(1).

Ewell, P. (2008). Building academic cultures of evidence: a perspective on learning outcomes in higher education. paper presented at the symposium of the Hong Kong University Grants Committee on Quality Education, Quality Outcomes - the way forward for Hong Kong, Hong Kong, June. Retrieved September 15, 2010 from www.ugc.edu.hk/eng/ugc/activity/outcomes/symposium/ 2008/present.html

Gneezy, A. (2017). Field experimentation in marketing research. Journal of Marketing Research, 54(1), 140-143. https://doi.org/10.1509/jmr.16.0225

Kapasi, I., \& Grekova, G. (2018). What do students think of selfdetermined learning in entrepreneurship education? Education+Training, 60(7/8). https://doi.org/10.1108/ET-02-2017-0028

Kerr, G. F., \& Waller, D. S. (2014). Advertising education in Australia. In Richards, J. I., \& Ross, B. I. (Eds,), Advertising Education Around the World, American Academy of Advertising, East Lansing, MI. https://doi.org/10.1177/0273475309345001

Kerr, G. F., Waller, D. S., \& Patti, C. (2009). Advertising education in Australia looking back to the future. Journal of Marketing Education, 31(3).

Lockheed, M., \& Jiménez, E. (1994). Public and private secondary schools in developing countries: what are the differences and why do they persist? The World Bank. Education and Social Policy Department, ESP Discussion Paper Series, No. 33. https://doi.org/10.1596/0-8213-3479-4

Manimala, M. J. (2006), Management education in India: a perspective on quality improvement. Journal of Management and Entrepreneurship, 1(3).

Nkhoma, C. A., Thomas, S., Nkhoma, M. Z., Sriratanaviriyakul, N., Truong, T. H., \& Vo, H. X. (2018). Measuring the impact of outofclass communication through instant messaging. Education+Training, 60(4). https://doi.org/10.1108/ET-12-2017-0196

Pride, W., Ferrell, O., Lukas, B., Schembri, S., \& Niininen, O. (2015), Marketing Principles (2nd ed.). Cengage Learning, South Melbourne.

Punia, B. K., \& Kundu, S. C. (2005). Management Education in India: Towards Quality Standards and Global Competitiveness, Deep \& Deep Publications Pvt Ltd, New Delhi.

Rao, P. S., \& Hans, K. (2011). Comparative analysis of accreditation systems in management education in India (NBA and SAQS). Aweshakar Research Journal, 12(2). 
Ritika, M., Rajat, A., Vinay, S., \& Vinay, N. (2014). Factors affecting quality of management education in India: An interpretive structural modelling approach. International Journal of Educational Management, 28(4). https://doi.org/10.1108/IJEM-10-2012-0115

Sahney, S., Banwet, D. K., \& Karunes, S. (2010). Quality framework in education through application of interpretive structural modeling: an administrative staff perspective in the Indian context. The TQM Journal, 22(1). https://doi.org/10.1108/17542731011009621

Sheedy, K., \& Russell, E. (2007). Evolution Through Innovation: A History of Marketing Education at Monash, Department of Marketing at Monash University, Melbourne.

Slack, N., BrandonJones, A., \& Johnston, R. (2016). Operations Management, 8th ed., Pearson Education Limited, Harlow.

Tapp, A. (2004). The changing face of marketing academia: what can we learn fromcommercial market research and practitioners? European Journal of Marketing, 38(5/6). https://doi.org/10.1108/03090560410529178

Thomas, H., \& Thomas, L. (2011). Perspectives on leadership in business schools. Journal of Management Development, 30(5). https://doi.org/10.1108/02621711111133037

\section{Copyrights}

Copyright for this article is retained by the author(s), with first publication rights granted to the journal.

This is an open-access article distributed under the terms and conditions of the Creative Commons Attribution license (http://creativecommons.org/licenses/by/4.0/). 